\title{
Studi Interaksi Molekuler Aktivitas Antimikroba Peptida Bioaktif terhadap Staphylococcus aureus Secara In silico
}

Taufik Muhammad Fakih*, Mentari Luthfika Dewi

Program Studi Farmasi, Fakultas Matematika dan Ilmu Pengetahuan Alam, Universitas Islam Bandung, Bandung, Indonesia

*Corresponding author: taufikmuhammadf@gmail.com

Submitted: 28 Maret 2020

Accepted: 10 Mei 2020

Published: 30 November 2020

\begin{abstract}
Background: Skin mucus of yellow catfish (Pelteobagrus fulvidraco) contains bioactive peptides and is widely used in treatment of various diseases because of their biological activity, including antimicrobial agent. Some of these bioactive peptides include pelteobagrin, myxinidin, pleurocidin, and pardaxin-PI and have been proven to be able to inhibit Penicillin-Binding Protein 3 (PBP3) of Staphylococcus aureus. Objective: This study aims to identify the antimicrobial activity of bioactive peptide molecules trough in silico against the Penicillin-Binding Protein 3 (PBP3) macromolecules of Staphylococcus aureus and interactions of these bioactive peptides that may be involved in this antimicrobial action. Methods: The sequencing bioactive peptide was firstly performed for modeling in the form of $3 D$ conformation using PEP-FOLD software. The best conformation of the modeling results was chosen and then a molecular docking study was done on the macromolecule of Staphylococcus aureus using PatchDock software. The molecular interactions product were then identified using the BIOVIA Discovery Studio 2020 software. Results: The results of molecular docking showed that the myxinidin bioactive peptide has the best affinity with an ACE score $-2497.26 \mathrm{~kJ} / \mathrm{mol}$. Conclusion: The bioactive peptide from yellow catfish (Pelteobagrus fulvidraco) was considerated to be used as a natural antimicrobial candidate.
\end{abstract}

Keywords: Pelteobagrus fulvidraco, bioactive peptide, penicillin-binding protein 3 (PBP3), Staphylococcus aureus

\begin{abstract}
Abstrak
Pendahuluan: Lendir kulit ikan lele kuning (Pelteobagrus fulvidraco), mengandung peptida bioaktif dan banyak dimanfaatkan dalam pengobatan berbagai penyakit karena memiliki aktivitas biologis, diantaranya sebagai antimikroba. Beberapa peptida bioaktif tersebut, antara lain pelteobagrin, myxinidin, pleurocidin, dan pardaxinP1 dan telah terbukti mampu menghambat Penicillin-Binding Protein 3 (PBP3) dari Staphylococcus aureus. Tujuan: Penelitian ini bertujuan untuk mengidentifikasi aktivitas antimikroba molekul peptida bioaktif secara in silico terhadap makromolekul Penicillin-Binding Protein 3 (PBP3) dari Staphylococcus aureus dan interaksi peptida bioaktif tersebut yang terlibat dalam mekanisme aksi antimikroba. Metode: Sekuensing peptida bioaktif terlebih dahulu dilakukan pemodelan ke dalam bentuk konformasi 3D menggunakan software PEP-FOLD. Konformasi terbaik hasil pemodelan dipilih untuk kemudian dilakukan studi penambatan molekuler terhadap makromolekul dari Staphylococcus aureus menggunakan software PatchDock. Interaksi molekuler yang terbentuk selanjutnya diidentifikasi lebih lanjut menggunakan software BIOVIA Discovery Studio 2020. Hasil: Berdasarkan hasil penambatan molekuler menunjukkan bahwa peptida bioaktif myxinidin memiliki afinitas paling baik dengan ACE score -2497,26 kJ/mol. Kesimpulan: Peptida bioaktif lendir kulit ikan lele kuning (Pelteobagrus fulvidraco) dapat dipertimbangkan sebagai kandidat antimikroba alami.
\end{abstract}

Kata kunci: Pelteobagrus fulvidraco, peptida bioaktif, Penicillin-Binding Protein 3 (PBP3), Staphylococcus aureus 


\section{PENDAHULUAN}

Pilihan terapi yang efektif untuk mencegah infeksi yang disebabkan oleh Staphylococcus aureus hingga saat ini masih terbatas. Hal tersebut menjadi dalam pengendalian Staphylococcus aureus (Boucher dkk., 2009). Staphylococcus aureus adalah bakteri Grampositif komensal yang berkoloni pada mukosa hidung manusia baik secara permanen atau sementara (Kluytmans dkk., 1997) dan akhirnya memperparah bagian yang terinfeksi (Kuehnert dkk., 2005; Klevens dkk., 2007). Gejala klinis tidak akan muncul sampai sistem kekebalan tubuh terpengaruh (Diefenbeck dkk., 2011). Masalah utama dalam mengendalikan infeksi Staphylococcus aureus adalah terjadinya resistensi multi-obat yang disebabkan karena penyalahgunaan antibiotika. Di samping itu juga dapat diakibatkan oleh pengobatan infeksi non-bakteri dengan antibiotika atau tingkat kepatuhan yang kurang terhadap aturan konsumsi obat. Oleh karena itu, diperlukan molekul terapi baru sebagai kandidat antibiotika dalam pengobatan infeksi Staphylococcus aureus. Beberapa penelitian telah membuktikan bahwa terdapat beberapa molekul peptida bioaktif yang berpotensi sebagai alternatif terbaik untuk mengembangkan terapi infeksi bakteri yang resisten terhadap beberapa obat (Garo dkk., 2007; Coutinho dkk., 2008; Coutinho dkk., 2009).

Penelitian terbaru mengungkapkan bahwa lendir permukaan ikan lele kuning (Pelteobagrus fulvidraco) mengandung molekul peptida bioaktif seperti pelteobagrin, myxinidin, pleurocidin, dan pardaxin-P1 (Su, 2011). Lendir ini merupakan perlindungan pertama terhadap mikroba yang hidup di air. Selain berguna sebagai penghalang fisik antara ikan dan lingkungannya, lendir ini juga telah terbukti memiliki aktivitas antimikroba yang dimediasi melalui serangkaian faktor kekebalan tubuh bawaan yang terdiri dari lisozim, lektin, enzim proteolitik, flavoenzim, imunoglobulin, dan protein C-reaktif (Ellis, 2001; Whyte, 2007; Subramanian dkk., 2008). Aktivitas antimikroba molekul peptida bioaktif ini antara lain mampu menghambat pertumbuhan mikroba, seperti bakteri Gram-positif dan Gram-negatif, jamur, virus, dan parasit. Selain itu, peptida ini juga berperan sebagai imunomodulator untuk meningkatkan imunitas tubuh (Bergsson dkk., 2005; Luders dkk., 2005; Subramanian dkk., 2009).

Pada penelitian ini akan dibuktikan lebih lanjut interaksi yang terjadi antara molekul peptida bioaktif dengan struktur reseptor target yang terdapat pada Staphylococcus aureus yaitu Penicillin-Binding
Protein 3 (PBP3) dari Methicillin-Resistant Staphylococcus aureus (MRSA) (Yoshida dkk., 2012). Studi komputasi dengan memanfaatkan metode penambatan molekuler berbasis protein-peptida dipilih untuk membandingkan molekul peptida bioaktif yang memiliki afinitas dan interaksi paling baik terhadap target reseptor sehingga dapat diperoleh struktur acuan sebagai kandidat peptida antimikroba.

\section{BAHAN DAN METODE}

\section{Bahan}

Bahan yang digunakan dalam penelitian ini adalah struktur kristal makromolekul protein PBP3 dari Staphylococcus aureus yang telah membentuk kompleks dengan cefotaxime. Makromolekul protein tersebut diperoleh dari web Protein Data Bank (http://www.rcsb.org/pdb) dengan kode PDB 3VSL dan memiliki resolusi 2,40 ̊ (Gambar 1) (Yoshida dkk., 2012). Kemudian, molekul peptida bioaktif yang digunakan dalam penelitian ini merupakan peptida bioaktif yang memiliki aktivitas terhadap Staphylococcus aureus dan telah dibuktikan melalui penelitian sebelumnya. Molekul peptida bioaktif tersebut adalah pelteobagrin, myxinidin, pleurocidin, dan pardaxin-P1 yang berasal dari lendir permukaan ikan lele kuning (Pelteobagrus fulvidraco) (Su, 2011).

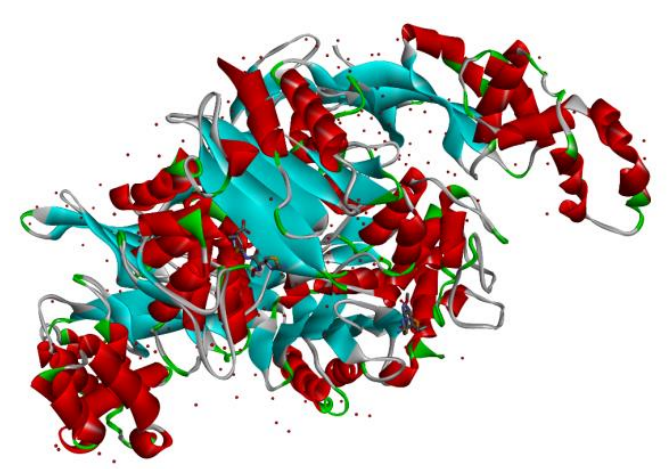

Gambar 1. Struktur kristal makromolekul protein dari Staphylococcus aureus yang membentuk kompleks dengan cefotaxime

\section{Alat}

Software yang digunakan dalam penelitian ini meliputi Sistem Operasi Windows 10 dan Linux Ubuntu 18.10, MGLTools 1.5.6 yang dilengkapi dengan AutoDock 4.2, PEP-FOLD (http://bioserv.rpbs.univ-paris-diderot.fr/PEP-FOLD/), PachDock, serta BIOVIA Discovery Studio 2020. Selain itu, hardware yang digunakan adalah komputer dengan spesifikasi processor Intel (R) Core i3-6100 
CPU @ 2.30GHz (4 CPUs), memory 4096 MB RAM, Harddisk 320GB, dan VGA Intel HD Graphics 520.

\section{Metode}

\section{Preparasi makromolekul protein}

Struktur kristal makromolekul protein yang telah diunduh dari web Protein Data Bank selanjutnya dilakukan preparasi terlebih dahulu menggunakan software MGLTools 1.5.6 yang dilengkapi dengan AutoDock 4.2. Preparasi makromolekul protein ini dilakukan dengan menghilangkan molekul air dan ligan alami, kemudian dilanjutkan dengan menambahkan atom hidrogen polar dan menghitung muatan parsial Kollman (Kurniawan dkk., 2018).

\section{Identifikasi area sisi aktif makromolekul protein}

Makromolekul protein yang telah dipreparasi kemudian diidentifikasi dan dievaluasi bagian sisi aktif pengikatan yang berperan terhadap aktivitas antimikroba dengan menggunakan software BIOVIA Discovery Studio 2020 (Kemmish dkk., 2017). Molekul cefotaxime yang merupakan ligan alami dari makromolekul protein PBP3 dari Staphylococcus aureus digunakan untuk mengidentifikasi dan mengevaluasi area sisi aktif dari makromolekul protein.

\section{Pemodelan molekul peptida bioaktif}

Pemodelan molekul peptida bioaktif dilakukan dengan menggunakan server PEP-FOLD (http://bioserv.rpbs.univ-paris-diderot.fr/PEP-FOLD/) (Gambar 2). Server PEP-FOLD merupakan suatu software yang digunakan untuk pemodelan sekuensing peptida bioaktif menjadi konformasi 3D menggunakan metode de novo dengan jumlah asam amino antara 9 sampai 25 (Chavan \& Deobagkar, 2015).

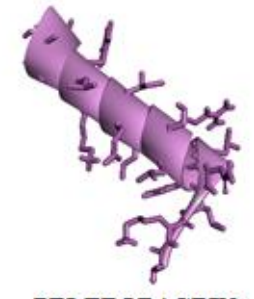

PELTEOBAGRIN

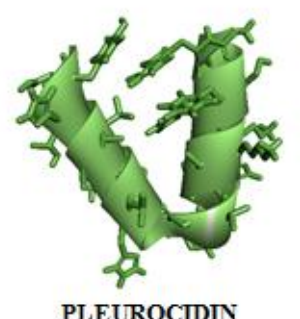

PLEUROCIDIN

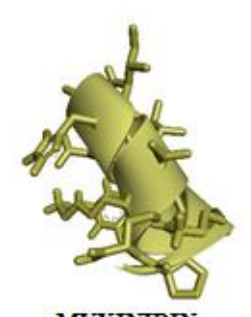

MYXINIDIN

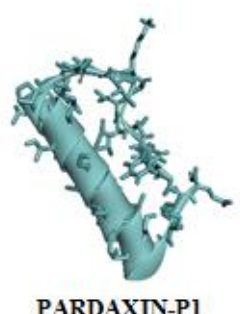

Gambar 2. Struktur molekul peptida bioaktif dari lendir permukaan ikan lele kuning (Pelteobagrus fulvidraco)
Simulasi penambatan molekuler berbasis proteinpeptida

Simulasi penambatan molekuler berbasis proteinpeptida dilakukan menggunakan software PatchDock untuk mengamati, mengidentifikasi, dan mengevaluasi afinitas molekul peptida bioaktif terhadap makromolekul protein PBP3 dari Staphylococcus aureus. Jarak antara bagian permukaan makromolekul protein dan molekul peptida bioaktif dibatasi dengan batas radius maksimum $4.0 \AA$ A. Simulasi penambatan molekuler ini menggunakan parameter berdasarkan representasi bentuk molekul, bagian sisi aktif pengikatan makromolekul protein, serta pemilihan dan penilaiannya. Simulasi ini juga dilakukan secara efisien tanpa adanya ikatan yang bersifat rigid antar molekul (Aruleba dkk., 2018).

Analisis hasil simulasi penambatan molekuler berbasis protein-peptida

Dari hasil penambatan molekuler berbasis proteinpeptida selanjutnya dilakukan identifikasi, evaluasi, dan eksplorasi terhadap interaksi molekuler yang terjadi antara makromolekul protein PBP3 dari Staphylococcus aureus dengan molekul peptida bioaktif berdasarkan Atomic Contact Energy (ACE) score (Prabhu \& Rajeswari, 2016). Residu asam amino yang bertanggung jawab terhadap interaksi molekuler yang terbentuk diamati dengan software BIOVIA Discovery Studio 2020.

\section{HASIL DAN PEMBAHASAN}

Peptida antimikrobial saat ini telah menjadi sumber pengobatan yang sangat penting dan banyak penelitian yang dilakukan terhadap aktivitas terapeutiknya. Dengan demikian, perlu dilakukan evaluasi aktivitas antimikroba terhadap lendir permukaan ikan lele kuning (Pelteobagrus fulvidraco). Protein PBP3 dari Staphylococcus aureus dipilih untuk dipelajari karena merupakan target penting pada bakteri patogen. Di samping itu, sebagian besar bakteri patogenik telah mengalami resistensi terhadap beberapa antibiotika yang tersedia saat ini, karena penyalagunaan atau penggunaannya yang berlebihan. Fenomena ini menjadikan kebutuhan mendesak untuk mengeksplorasi berbagai sumber agen antimikroba yang efektif, tidak toksik, dan hemat biaya (Subramanian dkk., 2008; Subramanian dkk., 2009). Penelitian ini bertujuan untuk mengidentifikasi peptida bioaktif yang memiki aktivitas antimikroba terhadap Staphylococcus aureus secara in silico. 
Penelitian sebelumnya membuktikan bahwa terdapat beberapa molekul peptida bioaktif dari lendir permukaan ikan lele kuning (Pelteobagrus fulvidraco) yang telah berhasil dikarakterisasi, dipreparasi, dan dipurifikasi. Proses pembuatan peptida bioaktif ini memanfaatkan proses sintesis organik, Microwave Assisted Extraction (MAE), hidrolisis kimia, dan hidrolisis enzim. Selanjutnya dilakukan proses pemurnian peptida bioaktif dengan menggunakan metode kromatografi eksklusi gel, kromatografi penukar ion, dan kromatografi cair kinerja tinggi. Beberapa peptida bioaktif yang memiliki aktivitas terhadap protein PBP3 dari Staphylococcus aureus, diantaranya adalah pelteobagrin, myxinidin, pleurocidin, dan pardaxin-P1 (Su, 2011).

Makromolekul protein PBP3 dari Staphylococcus aureus terlebih dahulu dilakukan preparasi dengan menghilangkan molekul air dan ligan alami yaitu cefotaxime, kemudian tahapan selanjutnya adalah menambahkan atom hidrogen polar, dan menghitung muatan parsial Kollman dengan menggunakan software MGLTools 1.5.6 yang dilengkapi dengan AutoDock 4.2 (Kurniawan dkk., 2018). Tahapan preparasi makromolekul protein ini bertujuan untuk memastikan bahwa molekul peptida bioaktif dapat menghasilkan afinitas yang baik pada bagian sisi aktif pengikatan makromolekul protein dan membentuk interaksi yang stabil. Selain itu, molekul cefotaxime yang telah membentuk kompleks dengan protein PBP3 dari Staphylococcus aureus digunakan sebagai senyawa pembanding untuk mengamati interaksi dan afinitasnya.

Setelah dilakukan preparasi terhadap makromolekul protein dari Staphylococcus aureus kemudian dilakukan identifikasi, evaluasi, dan eksplorasi pada bagian sisi aktifnya dengan menggunakan software BIOVIA Discovery Studio 2020 sehingga sifat dan karakteristik dari area pengikatan pada protein PBP3 dari Staphylococcus aureus dapat diketahui secara detail. Interaksi yang terjadi antara protein dari Staphylococcus aureus dengan cefotaxime (Gambar 3) meliputi 9 ikatan hidrogen (dengan Asn450, Ser488, Gln524, Thr619, Thr621, dan Glu623). Berdasarkan hasil pengamatan dapat diprediksi bahwa residu asam amino tersebut bertanggung jawab sebagai komponen penyusun pada bagian sisi aktif pengikatan makromolekul protein target.

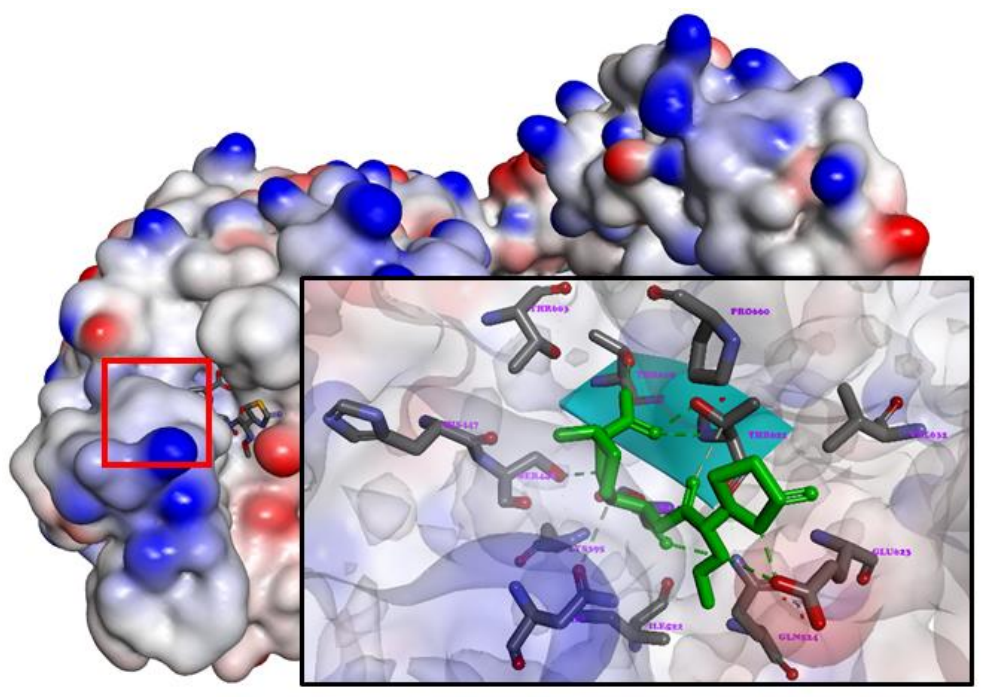

Gambar 3. Bagian sisi aktif pengikatan makromolekul protein dari Staphylococcus aureus

Pemodelan struktur tiga dimensi hasil sekuensing molekul peptida bioaktif dilakukan dengan server PEPFOLD. Konformasi peptida bioaktif terbaik dipilih berdasarkan energy sOPEP (Optimized Potential for Efficient Structure Prediction) (Thevenet dkk., 2012; Shen dkk., 2014). Energi sOPEP yang telah terintegrasi dalam server PEP-FOLD menggambarkan konformasi struktur peptida bioaktif yang dimodelkan mendekati keadaan aslinya, sehingga diharapkan mampu menghasilkan afinitas dan interaksi yang stabil dengan makromolekul protein target. Berdasarkan hasil pemodelan peptida bioaktif yang terdapat pada Tabel 1 dapat diprediksi bahwa peptida tersebut akan dapat berinteraksi dengan baik pada bagian sisi aktif pengikatan protein PBP3 dari Staphylococcus aureus. 
Tabel 1. Nilai energi sOPEP (Optimized Potential for Efficient Structure Prediction) molekul peptida bioaktif

\begin{tabular}{ccc}
\hline $\begin{array}{c}\text { Molekul peptida } \\
\text { bioaktif }\end{array}$ & Sekuensing molekul peptida bioaktif & $\begin{array}{c}\text { Energi sOPEP (Optimized Potential } \\
\text { for Efficient Structure Prediction })\end{array}$ \\
\hline Pelteobagrin & GKLNLFLSRLEILKLFVGAL & $-48,74$ \\
Myxinidin & GIHDILKYGKPS & $-14,75$ \\
Pleurocidin & GWGSFKKAAHVGKHVGKAAL & $-47,04$ \\
THYL & $-61,97$ \\
Pardaxin-P1 & GFFALIPKIISSPLFKTLLSAVGSA & LSSSGEQE \\
\hline
\end{tabular}

Simulasi penambatan molekuler berbasis proteinpeptida menggunakan software PatchDock dilakukan untuk mengamati afinitas paling baik diantara beberapa molekul peptida bioaktif, serta mengamati interaksi yang terbentuk dengan makromolekul protein PBP3 dari Staphylococcus aureus. Kompleks protein-peptida dengan konformasi terbaik hasil simulasi penambatan molekuler dipilih berdasarkan PatchDock score, kemudian molekul peptida bioaktif tersebut dibandingkan berdasarkan Atomic Contact Energy (ACE) score (Prabhu \& Rajeswari, 2016). Data hasil penambatan molekuler pada Tabel 2 menunjukkan bahwa peptida bioaktif myxinidin memiliki afinitas yang lebih baik dibandingkan cefotaxime dan peptida bioaktif lainnya, yaitu dengan ACE score -2497,26 kJ/mol. Hasil yang berbeda ditunjukkan oleh peptida bioaktif pleurocidin yang memiliki ACE score positif yaitu $183,05 \mathrm{~kJ} / \mathrm{mol}$. Fenomena tersebut dapat disebabkan oleh adanya interaksi yang tidak diinginkan (unfavorable bond) antara peptida bioaktif pleurocidin dengan makromolekul protein target (Veeraragavan dkk., 2017).

Tabel 2. Energi bebas pengikatan hasil simulasi penambatan molekuler berbasis protein-peptida

\begin{tabular}{ccc}
\hline Molekul uji & PatchDock score & ACE score $(\mathrm{kJ} / \mathrm{mol})$ \\
\hline Cefotaxime & 4742 & $-1390,47$ \\
Pelteobagrin & 10050 & $-176,31$ \\
Myxinidin & 7310 & $-2497,26$ \\
Pleurocidin & 9680 & 183,05 \\
Pardaxin-P1 & 10462 & $-1073,95$ \\
\hline
\end{tabular}

Selanjutnya dilakukan identifikasi dan evaluasi terhadap visualisasi kompleks molekul peptida bioaktif dan makromolekul protein target. Hasil pengamatan menunjukkan bahwa tidak terdapat perbedaan yang bermakna, karena sebagian besar peptida bioaktif berada pada bagian sisi aktif pengikatan protein PBP3 dari Staphylococcus aureus (Gambar 4). Apabila dilakukan perbandingan interaksi, peptida bioaktif myxinidin memiliki interaksi yang lebih banyak (Tabel 3). Interaksi yang terbentuk antara peptida bioaktif myxinidin dengan protein target meliputi 8 ikatan hidrogen (dengan Ser392, Ser429, Met446, Ser448, Thr619, Thr621, dan Trp662) dan 6 interaksi hidrofobik (dengan His447, Val658, Pro659, Pro661, dan Trp662). Hasil identifikasi ini membuktikan bahwa interaksi yang terbentuk antara peptida bioaktif myxinidin dan makromolekul protein PBP3 dari
Staphylococcus aureus memiliki ikatan yang stabil pada area sisi aktif pengikatan (Norel dkk., 2001).

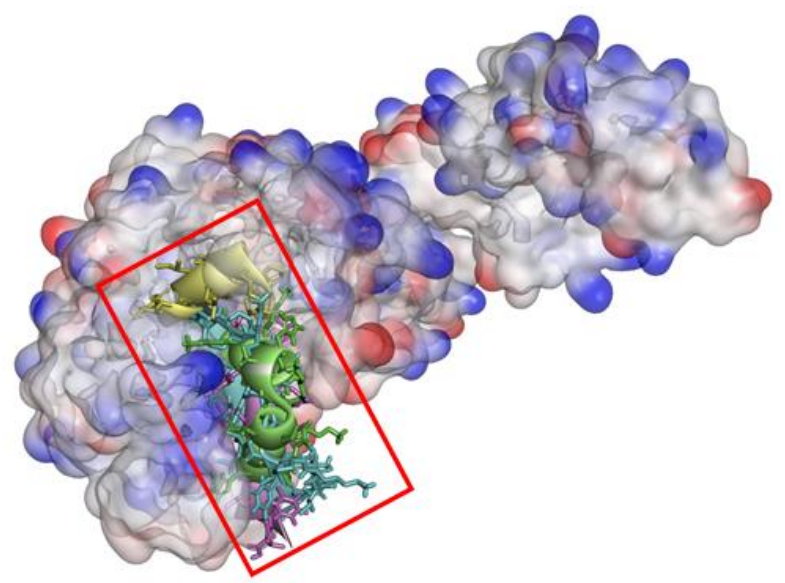

Gambar 4. Konformasi molekul peptida bioaktif pada sisi aktif pengikatan makromolekul protein dari Staphylococcus aureus 
Tabel 3. Interaksi hasil simulasi penambatan molekuler berbasis protein-peptida

\begin{tabular}{ccc}
\hline Molekul uji & Jumlah interaksi & Residu asam amino \\
\hline Cefotaxime & 10 & Ser392, Val606, Thr619, Thr621, Ser634, Tyr636, \\
Pelteobagrin & 6 & Pro661, Leu663, \\
Myxinidin & 14 & $\begin{array}{c}\text { Ser392, Asn432, Leu471, Leu518, Thr621, Pro659 } \\
\text { Ser392, Ser429, Met446, His447, Ser448, Thr619, } \\
\text { Thr621, Val658, Pro659, Pro661, Trp662 }\end{array}$ \\
Pleurocidin & 13 & Ser392, Phe421, Leu425, Lys427, Ser429, Asn432, \\
Pardaxin-P1 & 12 & Leu471, Gln524, Thr621, Glu623, \\
& & Leu425, Lys427, Ser429, Phe454, Leu471, Pro514, \\
\end{tabular}

\section{KESIMPULAN}

Peptida bioaktif myxinidin memiliki afinitas yang paling baik dibandingkan peptida bioaktif lainnya dengan ACE score $-2497,26 \mathrm{~kJ} / \mathrm{mol}$ dan berpotensi untuk dikembangkan sebagai kandidat antimikroba alami.

\section{DAFTAR PUSTAKA}

Aruleba, R. T., Adekiya, T. A., Oyinloye, B. E. \& Kappo, A. P. (2018). Structural Studies of Predicted Ligand Binding Sites and Molecular Docking Analysis of Slc2a4 as a Therapeutic Target for the Treatment of Cancer. International Journal of Molecular Sciences; 19; 386.

Bergsson, G., Agerberth, B., Jornvall, H. \& Gudmundsson, G. H. (2005). Isolation and Identification of Antimicrobial Components from the Epidermal Mucus of Atlantic Cod (Gadus morhua). The FEBS Journal; 272; 49604969.

Boucher, H. W., Talbot, G. H., Bradley, J. S., Edwards, J. E., Gilbert, D., Rice, L. B., Scheld, M., Spellberg, B. \& Bartlett, J. (2009). Bad Bugs, No Drugs: no ESKAPE! An Update from the Infectious Diseases Society of America. Clinical Infectious Diseases; 48; 1-12.

Chavan, S. G. \& Deobagkar, D. D. (2015). An in silico Insight into Novel Therapeutic Interaction of LTNF Peptide-LT10 and Design of Structure Based Peptidomimetics for Putative AntiDiabetic Activity. PLoS One; 10; 0121860.

Coutinho, H. D., Costa, J. G., Lima, E. O., FalcaoSilva, V. S. \& Siqueira-Junior, J. P. (2008). Enhancement of the Antibiotic Activity Against a Multiresistant Escherichia coli by Mentha arvensis L. and Chlorpromazine. Chemotherapy; 4; 328-330.

Coutinho, H. D., Costa, J. G., Lima, E. O., FalcaoSilva, V. S. \& Siqueira-Junior, J. P. (2009).
Herbal Therapy Associated with Antibiotic Therapy: Potentiation of the Antibiotic Activity Against Methicillin-Resistant Staphylococcus aureus by Turnera ulmifolia L. BMC Complementary and Alternative Medicine; 9; 13. Diefenbeck, M., Mennenga, U., Guckel, P., Tiemann, A.H., Muckley, T., \& Hofmann, G.O. (2011) Vacuum-assisted Closure Therapy for the Treatment of Acute Postoperative Osteomyelitis. Z Orthop Unfall; 149; 336-341.

Ellis, A. E. (2001). Innate Host Defense Mechanisms of Fish Against Viruses and Bacteria. Developmental and Comparative Immunology; $25 ; 827-839$.

Garo, E., Eldridge, G. R., Goering, M. G., DeLancey, P. E., Hamilton, M. A., Costerton, J. W. \& James, G. A. (2007). Asiatic Acid and Corosolic Acid Enhance the Susceptibility of Pseudomonas aeruginosa Biofilms to Tobramycin. Antimicrobial Agents and Chemotherapy; 51; 1813-1817.

Kemmish, H., Fasnacht, M. \& Yan, L. (2017). Fully Automated Antibody Structure Prediction using BIOVIA Tools: Validation Study. PLoS One; 12: e0177923.

Klevens, R. M., Morrison, M. A., Nadle, J., Petit, S., Gershman, K., Ray, S., Harrison, L. H., Lynfield, R., Dumyati, G., Townes, J. M., Craig, A. S., Zell, E. R., Fosheim, G. E., McDougal, L. K., Carey, R. B. \& Fridkin, S. K. Active Bacterial Core surveillance (ABCs) MRSA Investigatorset Al. Invasive MethicillinResistant Staphylococcus aureus Infections in the United States. Jama; 298; 1763-1771.

Kluytmans, J., van Belkum, A. \& Verbrugh, H. (1997). Nasal Carriage of Staphylococcus aureus: Epidemiology, Underlying Mechanisms, and Associated Risks. Clinical Microbiology Reviews; 10; 505-520. 
Kuehnert, M. J., Hill, H. A., Kupronis, B. A., Tokars, J. I., Solomon, S. L. \& Jernigan, D. B. Methicillinresistant-Staphylococcus aureus hospitalizations, United States. Emerging Infectious Diseases; 11; 868-872.

Kurniawan, F., Miura, Y., Kartasasmita, R. E., Yoshioka, N., Mutalib, A. \& Tjahjono, D. H. (2018). In Silico Study, Synthesis, and Cytotoxic Activities of Porphyrin Derivatives. Pharmaceuticals; 11; 8 .

Luders, T., Birkemo, G. A., Meyer, J. N., Andersen, O. \& Nes, I. F. (2005) Proline Conformation Dependent Antimicrobial Activity of a ProlineRich Histone H1 N-terminal Peptide Fragment Isolated from the Skin Mucus of Atlantic Salmon. Antimicrobial Agents and Chemotherapy; 49; 2399-2406.

Norel, R., Sheinerman, F., Petrey, D. \& Honig, B. (2001). Electrostatic Contributions to ProteinProtein Interactions: Fast Energetic Filters for Docking and Their Physical Basis. Protein Science; 10; 2147-2161.

Prabhu, D. S. \& Rajeswari, V. D. (2016). In Silico Docking Analysis of Bioactive Compounds from Chinese Medicine Jinqi Jiangtang Tablet (JQJTT) using Patch Dock. Journal of Chemichal and Pharmaceutical Research; 8; 15-21.

Shen, Y., Maupetit, J., Derreumaux, P. \& Tuffery P. (2014). Improved PEP-FOLD Approach for Peptide and Miniprotein Structure Prediction. Journal of Chemical Theory and Computation; $10 ; 4745-4758$.

$\mathrm{Su}, \mathrm{Y}$. (2011) Isolation and Identification of Pelteobagrin, A Novel Antimicrobial Peptide from the Skin Mucus of Yellow Catfish
(Pelteobagrus fulvidraco). Comparative Biochemistry and Physiology; 158; 149-154.

Subramanian, S., Ross, N. W. \& MacKinnon, S. L. (2008). Comparison of Antimicrobial Activity in the Epidermal Mucus Extracts of Fish. Comparative Biochemistry and Physiology; 150; 85-92.

Subramanian, S., Ross, N. W., \& MacKinnon, S. L. (2009). Myxinidin, A Novel Antimicrobial Peptide from the Epidermal Mucus of Hagfish, Myxine glutinosa L. Marine Biotechnology; 11; 748-757.

Thevenet, P., Shen, Y., Maupetit, J., Guyon, F., Derreumaux, P. \& Tuffery, P. (2012). PEPFOLD: An Updated De Novo Structure Prediction Server for Both Linear and Disulfide Bonded Cyclic Peptides. Nucleic Acids Research; 40; 288-293.

Veeraragavan, V., Narayanaswamy, R. \& Chidambaram, R. (2017). Predicting the Biodegradability Nature of Imidazole and Its Derivatives by Modulating Two Histidine Degradation Enzymes (Urocanase and Formiminoglutamase) Activities. Asian Journal Pharmaceutical and Clinical Research; 10; 383386.

Whyte, S. K. (2007). The Innate Immune Response of Finfish - A Review of Current Knowledge. Fish and Shellfish Immunology; 23; 1127-1151.

Yoshida, H., Kawai, F., Obayashi, E., Akashi, S., Roper, D. I., Tame, J. R. H. \& Park, S. Y. (2012) Crystal Structures of Penicillin-Binding Protein 3 (PBP3) from Methicillin-Resistant Staphylococcus aureus in the Apo and Cefotaxime-Bound Forms. Journal of Molecular Biology; 423; 351-364. 